Today, desertification is a global problem. U.N. experts have recently calculated that the rate of desert spread today is 31,000 square miles each year, and the situation becomes particularly acute when one realizes onethird of the earth's land area is arid - the most susceptible region to desertification - on which some 650 million people live.

Admittedly, vulnerability and susceptibility to desertification, as well as its severity, are strongly influenced by climatic conditions, that is, the less amount and more uncertain the rainfall, the greater potential there is for desertification to occur. Nevertheless, in recent years, the greatest liability leading to desertified areas has been land-use pressure, particularly in the intensification of population densities, pastoral migrations, and the introduction of mechanized agriculture. Desertification is thus a human phenomenon, stimulated both by man's quest for livelihood and acceptance of new technologies and dry-land environments.

The forum for organizing the global antidesertification campaign came to the United Nations, specifically the U.N. Conference on Desertification which convened in Nairobi, Kenya, from August 29-September 9, 1977.

So, progress and remedial programs have been forthcoming. The critical question still persists, however, of whether it is too little, too late. To conclude, one must evaluate the real prospects of programs for halting the spread of desert lands. Over the long term there might be room for cautious optimism; in the short term, however, the picture is far less certain.

\title{
ANNUAL DINNER
}

\section{ROBERT D. HODGSON In Memoriam*}

At its Fall meeting in 1979, on the suggestion of a distinguished nonAmerican member of the Society, the Executive Council voted a resolution of special commendation to Robert Hodgson, late Geographer of the Department of State and member for a number of years of the American Society of International Law. This was an extraordinary step. There are number of awards for intellectual and professional merit regularly made by the Society. But for us, a spontaneously generated ad hoc gesture of recognition of this sort is, in recent memory at least, unprecedented.

It is perhaps all the more extraordinary because, while it is now formally announced posthumously, the resolution itself was adopted before Bob Hodgson's sudden and quite untimely death. And it is remarkable also because Robert Hodgson was not a lawyer, and because lawyers - who numerically predominate in our organization - while we are the first to assert our own universal competence, are often less eager to recognize the worth of others in fields beyond their principal vocation.

* Occasioned by a resolution of the Executive Council of the American Society of International Law, October 27, 1979. Remarks delivered by the Director of Studies at the Annual Dinner, April 18, 1980. 
Robert Hodgson's principal vocation was science: he was a geographer, of the highest technical competence. More that that, he was a political geographer, interested by experience, training and personal disposition in the implications of his science for the conduct of human affairs, and for the practical solution of problems of international life at every level.

While in recent years he was best known for his work on issues of jurisdiction and resource mangement in the oceans (the "Limits in the Seas" series is rightly regarded as an invaluable tool for makers of international law and policy the world over), his quiet competence was also brought to bear on some of the most troubling political-territorial disputes of his time. $\mathrm{He}$ moved easily and unassumingly among representatives of all professions, and persons of all nationalities, similarly involved. In the singular case of the protracted United Nations negotiations for a new law of the sea, the widespread confidence he commanded as a scientist and as a person had ppaced him in the position of a global resource-a colleague said "geographer to the world". In this role he perhaps embodied an earlier ideal of American leadership in outgoing and generous commitment to the success of the institutions of global cooperation - an ideal never perfectly realized, of course, and which successive years of frustration may now have left a bit tattered.

In sum, Robert Hodgson's contributions to the development of international legal order were superlative. Beyond that, he was unfailingly respected by those with whom he worked as a person of unremitting good humor, intellectual excellence, honesty and fairness.

\section{THE COMMITMENT TO INTERNATIONALISM}

\section{by Hans Blix*}

It is obvious that more and more of the great problems of our time cannot be solved except through international action. Even great powers and superpowers, who are better equipped than others to take care of their own problems, recognize that they must resort increasingly to joint action with others and to accommodation with others in order to achieve desired results.

Ever larger sectors of the government and, indeed, of other parts of our communities are engaged in the management of international relations because ever larger sectors of our lives are affected by events abroad. As the interdependence between states and continents is growing, our commitment to internationalism expands. The process is rapid. While important parts of classical internationl law focused on such essentially procedural matters as diplomatic and consular relations, treaties and state responsibility, between the wars, Manley $\mathrm{O}$. Hudson was able to publish his many volumes of International Legislation, demonstrating how many matters of substance were regulated by convention. Today a compilation of this comprehensive character would hardly be feasible. There is too much material.

In this process, where economists, ecologists, military men, health officials and many, many others join in the slow weaving of an international social

"Under Secretary of State, Ministry of Foreign Affairs, Sweden; formerly Foreign Minister. 